\title{
EFFECTS OF LONG-TERM REDUCED TILLAGE ON WEED INFESTATION OF PEA (Pisum sativum L.)
}

\author{
${ }^{1}$ Andrzej Woźniak, ${ }^{2}$ Myroslawa Soroka \\ ${ }^{1}$ Department of Herbology and Plant Cultivation Techniques, University of Life Sciences in Lublin, Poland \\ e-mail: andrzej.wozniak@up.lublin.pl \\ ${ }^{2}$ Department of Botany, Ukrainian National Forestry University, 79057 Lviv
}

Received: 10.08.2013

\begin{abstract}
The study evaluated weed infestation of pea (Pisum sativum L.) cultivated under conditions of conventional (CT), reduced (RT) and herbicide tillage (HT). It demonstrated the highest weed density per $\mathrm{m}^{2}$ in plots with the herbicide (HT) and reduced (RT) systems and significantly lower weed infestation in plots cultivated in the conventional system (CT). In addition, more weeds occurred at the third leaf stage (13/14 in $\mathrm{BBCH}$ scale) than at the pod development stage $(73 / 74 \mathrm{BBCH})$ of pea. The highest biomass was produced by weeds in the herbicide system (HT), a lower one - in the reduced system (RT), and the lowest one - in the conventional system (CT). The air-dry weight of weeds depended also on pea development stage. At the pod development stage $(73 / 74 \mathrm{BBCH})$, the air-dry weight of weeds was significantly higher than at the third leaf stage (13/14 BBCH). The tillage system was also observed to influence the species composition of weeds. This trait was also affected by the period of weed infestation assessment. At the third leaf stage of pea (13/14 BBCH), there occurred 26 weed species, including 24 annual ones. The most abundant species included: Chenopodium album L., Stellaria media (L.) Vill., Capsella bursa-pastoris (L.) Med., Matricaria inodora L., Thlaspi arvense L., and Fallopia convolvulus (L.) A. Löve. At the pod development stage $(73 / 74 \mathrm{BBCH})$, the pea crop was colonized by 24 weed species, including 3 perennial ones. At this stage the predominant species included: Avena fatua L., Amaranthus retroflexus L., Papaver rhoeas L., Echinochloa crus-galli (L.) P.B., Matricaria inodora L., and Galeopsis tetrahit $\mathrm{L}$.
\end{abstract}

Key words: Pisum sativum L., tillage system, weeds number, air-dry weight of weeds, species composition

\section{INTRODUCTION}

Weed infestation of crops results from the coeffects of agronomic practices and the soil seed bank
[1-3]. Weed density and biomass in a crop and species composition of weeds depend on the number of tillage operations and on the method and period of their application [4-6]. The opinions on the impact of notill system on the extent of weed infestation are much diversified [7]. D a v is et al. [8] and Peig né et al. [9] report than ploughless tillage increases weed infestation and resultantly decreases crop yield. In contrast, Tuesca et al. [10] demonstrate that the ploughing system increases weed infestation, whereas the no-till system reduces it as no weed diaspores emerge from the deeper layers of soil. According to Tørresen and $\mathrm{S} \mathrm{ku}$ te rud [11], ploughless tillage increases the diaspore bank in the topsoil from where seeds germinate, thus increasing weed infestation of the after-crop [12-14]. In turn, the investigations by $\mathrm{M} \mathrm{a} \mathrm{e} \mathrm{ck}$ a et al. [15] and by Falty n and Kordas [16] showed increased weed infestation of cereals under the conventional (ploughing) system, compared to the reduced system and direct seeding. In contrast, $\mathrm{K} \mathrm{r}$ a s k a and $\mathrm{P}$ a ł y s [17] reported higher weed biomass in barley sown under ploughless tillage conditions than that for plough tillage. Also in a study by W oźn i a k $[3,18]$, the reduced and herbicide tillage systems increased weed infestation in the plots compared to the conventional system.

The aim of this study was to determine the effect of long-term reduced tillage on the number and air-dry weight of weeds and on their species composition in a pea crop at the third true leaf (13/14 in BBCH scale) and pod development $(73 / 74 \mathrm{BBCH})$ stages of pea.

\section{MATERIALS AND METHODS}

A field experiment assessed the effect of three tillage methods, used over a period of 7 years (2007- 
2013), on weed infestation of pea in 2013 at the Uhrusk Experimental Station (51 ${ }^{\circ} 18^{\prime} 12^{\prime \prime} N, 23^{\circ} 36^{\prime} 50^{\prime \prime}$ E). The experiment was established in a randomized complete block design $(8 \mathrm{~m} \times 75 \mathrm{~m})$ in three replications. It evaluated weed infestation of pea (Pisum sativum L.) sown under three tillage systems: a) conventional tillage (CT); b) reduced tillage (RT); and c) herbicide tillage (HT). The conventional tillage (CT) system included shallow ploughing and harrowing after harvest of the previous crop (spring wheat) and ploughing in the autumn. Reduced tillage only involved the use of a cultivator in the autumn, whereas herbicide tillage was limited to treatment with the herbicide Roundup 360 SL (a.s. glyphosate) $-41 \mathrm{ha}^{-1}$. In the springtime, the tillage system including a cultivator, a string roller and a harrow was used in all plots.

The experiment was established on chalk rendzina with the granulometric composition of light, poor, sandy loam, classified as Rendzic Phaeozem by the IUSS Working Group WRB [19]. This soil is rich in available forms of phosphorus (214 mg P kg potassium (237 mg K kg${ }^{-1}$ ), and has a slightly alkaline $\mathrm{pH}$ value $\left(\mathrm{pH}_{\mathrm{KCl}}=7.2\right)$. The total nitrogen $(\mathrm{N})$ content in the soil is $1.03 \mathrm{~g} \mathrm{~N} \mathrm{~kg}^{-1}$, whereas that of organic carbon (C-organic) $-7.60 \mathrm{~g} \mathrm{~kg}^{-1}$.

Pea (Pisum sativum L.), cv. 'Tarchalska', was sown in the first decade of April, at the rate of 100 seeds per $\mathrm{m}^{2}$ at a row spacing of $20 \mathrm{~cm}$. Before sowing, the following doses of nitrogen, phosphorus and potassium were applied: $20 \mathrm{~kg} \mathrm{~N} \cdot \mathrm{ha}^{-1}, 17.5 \mathrm{~kg} \mathrm{P}$ ha $^{-1}$ and $66.5 \mathrm{~kg} \mathrm{~K} \mathrm{ha}^{-1}$. Pea crops were harrowed twice: first before sprouting and then at the third leaf stage of pea (13/14 in BBCH scale) [20].

In the last year of the study (2013), pea plant density after sprouting and weed infestation of the pea crop were evaluated in all plots. Plant density was determined per $\mathrm{m}^{2}$ of each plot at the leaf development stage $(10 / 11 \mathrm{BBCH})$. Weed infestation was examined

using the botanical-gravimetric method at two developmental stages, i.e.: the third true leaf $(13 / 14 \mathrm{BBCH})($ before harrowing of crops) and pod development (73/74 $\mathrm{BBCH})$. Weed infestation assessment consisted in the determination of the species composition of weeds as well as of the number and air-dry weight of weeds per $\mathrm{m}^{2}$ of each plot. This area was determined at random (twice) using a $1 \mathrm{~m} \times 0.5 \mathrm{~m}$ frame. The determination of air-dry weight of weeds consisted in the collection of all weeds from the frame, removing their root system and placing them on openwork shelves in an airy and dry place until constant weight was reached.

The results were elaborated analyzed using analysis of variance and the differences observed were estimated with Tukey's test at a significance level of $\mathrm{p}<0.05$.

\section{RESULTS}

The highest weed density per $\mathrm{m}^{2}$ was determined in the plots with the herbicide (HT) and reduced (RT) tillage systems, whereas significantly lower weed density - by $47.6-48.7 \%$ - was found under the conventional system $(\mathrm{CT})$ - Table 1 . Weed density per $\mathrm{m}^{2}$ was also observed to depend on the pea developmental stage. More weeds were recorded at the third leaf stage $(13 / 14 \mathrm{BBCH})$ than at the pod development stage (73/74 BBCH). At the first time of weed infestation assessment (stage 13/14 BBCH), a significantly higher number of weeds occurred in the plots cultivated under the reduced (RT) and herbicide (HT) systems in relation to the conventional one (CT). The differences between the CT system and the RT and HT plots reached 57.1 and $53.1 \%$, respectively. In turn, at the pod development stage $(73 / 74 \mathrm{BBCH})$ the highest weed density was determined in the herbicide and reduced tillage systems, whereas a significantly lower one for conventional tillage.

Table 1

Number of weeds per $\mathrm{m}^{2}$ in the pea crop

\begin{tabular}{ccccc}
\hline \multirow{2}{*}{$\begin{array}{c}\text { Growth stage (GS) } \\
\text { in BBCH scale }\end{array}$} & \multicolumn{3}{c}{ Tillage systems (TS) } & \multirow{2}{*}{ Mean } \\
\cline { 2 - 4 } & conventional (CT) & reduced (RT) & herbicide (HT) & 69.4 \\
\hline $13 / 14$ & 38.1 & 88.9 & 81.2 & 57.2 \\
\hline $73 / 74$ & 40.1 & 60.3 & 71.2 & - \\
\hline Mean & 39.1 & 74.6 & 76.2 & \\
\hline LSD $_{0.05}$ for TS - 12.1; GS - 8.3; TS x GS - 19.3 & & \\
\hline
\end{tabular}

The analysis of the other weed infestation parameter, i.e. air-dry weight of weeds, demonstrated that the highest biomass of weeds was produced under the herbicide system, it was lower in the case of re- duced tillage (RT) and lowest for the conventional system (CT). The difference between the highest weight of weeds in the HT plots and the lowest weed weight in the CT plots reached $67.5 \%$ (Table 2). The air-dry 
weight of weeds was also influenced by the pea development stage. At stage 73/74 (in BBCH scale), the weed weight was higher by $53.9 \%$ than at stage $13 / 14$ $(\mathrm{BBCH})$. On the first evaluation date, i.e. at the third leaf stage (13/14 BBCH), the air-dry weight of weeds was higher in the plots cultivated in the HT and RT systems, compared to the CT plots. In turn, at the pod development stage (73/74 $\mathrm{BBCH})$, significant differ- ences occurred between all plots, by the highest biomass was produced by weeds in the HT system, lower one - in RT, and the lowest one - in the CT system. The higher weed infestation and the higher weed biomass observed in the plots with the herbicide (HT) and reduced (RT) systems, compared to the CT plots, could be due to significantly poorer emergence of pea in the plots with ploughless tillage (HT and RT) (Table 3).

Table 2

Air-dry weight of weeds in $\mathrm{g} \times \mathrm{m}^{-2}$ in the pea crop

\begin{tabular}{ccccc}
\hline \multirow{2}{*}{$\begin{array}{c}\text { Growth stage (GS) } \\
\text { in BBCH scale }\end{array}$} & \multicolumn{3}{c}{ Tillage systems (TS) } & Mean \\
\cline { 2 - 4 } & conventional (CT) & reduced (RT) & herbicide (HT) & \\
\hline $13 / 14$ & 14.9 & 53.1 & 65.9 & 44.6 \\
$73 / 74$ & 49.1 & 109.9 & 131.1 & 96.7 \\
\hline Mean & 32.0 & 81.5 & 98.5 & - \\
\hline LSD $_{0.05}$ for TS - 10.3; GS - 8.3; TS x GS - 17.1 & & \\
\hline
\end{tabular}

Table 3

Pea plant density per $\mathrm{m}^{2}$ at the third leaf stage (10/11 in BBCH scale)

\begin{tabular}{cccc}
\hline \multicolumn{3}{c}{ Tillage systems (TS) } & Mean \\
\hline conventional (CT) & reduced (RT) & herbicide (HT) & \\
\hline 81 & 56 & 51 & 63 \\
\hline $\mathrm{LSD}_{0.05}$ for TS -14 & & & \\
\hline
\end{tabular}

At the first time of weed infestation assessment, i.e. at the third leaf stage (13/14 BBCH), 26 weed species were recorded, including 24 annual ones (Table 4). In the CT plots, the analysis showed 19 species with the most abundant ones including: Chenopodium album L., Stellaria media (L.) Vill., Capsella bursapastoris (L.) Med., Matricaria inodora L., Galinsoga parviflora Cav., and Avena fatua L. In total, they constituted over $67 \%$ of the whole weed community. The plots with the RT system were infested by 19 annual species, quantitatively predominated by: Chenopodium album L., Stellaria media (L.) Vill., Thlaspi arvense L., Matricaria inodora L., Avena fatua L., and Capsella bursa-pastoris (L.) Med. As a result, the above species represented over $67 \%$ of the weed community. In the herbicide tillage (HT) system, the analysis revealed 19 weed species, including 2 perennial ones. Their most abundant representatives included: Chenopodium album L., Stellaria media (L.) Vill. Capsella bursapastoris (L.) Med., Matricaria inodora L., Thlaspi arvense $\mathrm{L}$. and Viola arvensis Murr. In total, these species constituted $75 \%$ of the weed community.
On the second date of weed infestation analysis, i.e. at the pod development stage (stage $73 / 74 \mathrm{BBCH}$ ), the plots were colonized by 24 weed species, including 3 perennial ones (Table 5). In the CT plots, there occurred 18 species, including 2 perennial ones. They were predominated by: Avena fatua L., Amaranthus retroflexus L., Echinochloa crus-galli (L.) P.B., Papaver rhoeas L., Galinsoga parviflora Cav., and Fallopia convolvulus L. In total, these species constituted $77 \%$ of the weed community in this tillage system. The plots with reduced tillage were colonized by 23 weed species, including 3 perennial ones. The most abundant included: Avena fatua L., Chenopodium album L., Amaranthus retroflexus L., Papaver rhoeas L., Galeopisis tetrahit L., and Matricaria inodora L. They all represented $73 \%$ of the weed community. In turn, in the plots with herbicide tillage (HT) the analysis showed 17 weed species with the most abundant ones including: Avena fatua L., Amaranthus retroflexus L., Papaver rhoeas L., Matricaria inodora L., Chenopodium album L., and Capsella bursa-pastoris (L.) Med. The above species constituted more than $77 \%$ of the weed community. 
Table 4

Species composition and number of weeds per $\mathrm{m}^{2}$ in the pea crop at the third leaf stage (13/14 in BBCH scale)

\begin{tabular}{|c|c|c|c|}
\hline \multirow{2}{*}{ Species composition } & \multicolumn{3}{|c|}{ Tillage systems } \\
\hline & $\mathrm{CT}^{*}$ & $\mathrm{RT}$ & HT \\
\hline \multicolumn{4}{|l|}{ I. Annual weeds } \\
\hline Chenopodium album $\mathrm{L}$. & 8.9 & 24.1 & 19.8 \\
\hline Stellaria media (L.) Vill. & 4.5 & 9.8 & 12.5 \\
\hline Capsella bursa-pastoris (L.) Med. & 4.5 & 5.4 & 10.5 \\
\hline Matricaria inodora $\mathrm{L}$. & 2.8 & 6.5 & 7.2 \\
\hline Galinsoga parviflora $\mathrm{Cav}$. & 2.5 & - & - \\
\hline Avena fatua $\mathrm{L}$. & 2.5 & 6.5 & - \\
\hline Thlaspi arvense $\mathrm{L}$. & 2.2 & 7.5 & 6.8 \\
\hline Fallopia convolvulus (L.) A. Löve & 1.8 & 3.9 & 4.2 \\
\hline Galium aparine $\mathrm{L}$. & 1.2 & 2.8 & - \\
\hline Papaver rhoeas L. & 1.2 & 1.2 & 0.4 \\
\hline Poa aпnиа $\mathrm{L}$. & 1.2 & - & - \\
\hline Veronica persica Poir. & 0.8 & 4.9 & 3.9 \\
\hline Anagallis arvensis $\mathrm{L}$. & 0.8 & 0.8 & 0.9 \\
\hline Amaranthus retroflexus $\mathrm{L}$. & 0.8 & 7.5 & - \\
\hline Lamium amplexicaule $\mathrm{L}$. & 0.7 & - & 4.3 \\
\hline Viola arvensis Murr. & 0.5 & - & 4.5 \\
\hline Consolida regalis Gray. & 0.5 & 1.2 & 2.2 \\
\hline Galeopsis tetrahit $\mathrm{L}$. & - & 0.9 & - \\
\hline Sonchus asper (L.) Hill. & - & 0.9 & 1.0 \\
\hline Polygonum lapathifolium $\mathrm{L}$. & - & 0.2 & 0.2 \\
\hline Apera spica-venti (L.) P.B. & - & 2.5 & 1.2 \\
\hline Vicia villosa $\mathrm{L}$. & - & 2.1 & 0.2 \\
\hline Echionochloa crus-galli (L.) P.B. & - & 0.2 & - \\
\hline Centaurea cyanus L. & - & - & 0.4 \\
\hline Number of annual weeds (I) & 37.4 & 88.9 & 80.2 \\
\hline \multicolumn{4}{|l|}{ II. Perennial weeds } \\
\hline Cirsium arvense (L.) Scop. & 0.5 & - & 0.8 \\
\hline Convolvulus arvensis $\mathrm{L}$. & 0.2 & - & 0.2 \\
\hline Number of perennial weeds (II) & 0.7 & - & 1.0 \\
\hline Number of species & 19 & 19 & 19 \\
\hline
\end{tabular}

* CT- conventional tillage, $\mathrm{RT}$ - reduced tillage, $\mathrm{HT}$ - herbicide tillage 
Table 5

Species composition and number of weeds per $\mathrm{m}^{2}$ in the pea crop at the pod development stage (73/74 in $\mathrm{BBCH}$ scale)

\begin{tabular}{|c|c|c|c|}
\hline \multirow{2}{*}{ Species composition } & \multicolumn{3}{|c|}{ Tillage systems } \\
\hline & $\mathrm{CT}^{*}$ & RT & HT \\
\hline \multicolumn{4}{|l|}{ I. Annual weeds } \\
\hline Avena fatua $\mathrm{L}$. & 8.2 & 12.2 & 13.8 \\
\hline Amaranthus retroflexus L. & 6.2 & 8.9 & 12.2 \\
\hline Echinochloa crus-galli (L.) P.B. & 5.2 & 2.8 & 4.8 \\
\hline Papaver rhoeas $\mathrm{L}$. & 4.4 & 5.2 & 10.5 \\
\hline Galinsoga parviflora Cav. & 4.3 & 0.8 & - \\
\hline Fallopia convolvulus (L.) A. Löve & 2.5 & 0.8 & 2.5 \\
\hline Chenopodium album $\mathrm{L}$. & 2.5 & 10.3 & 6.2 \\
\hline Galeopsis tetrahit L. & 2.2 & 3.9 & 2.2 \\
\hline Matricaria inodora $\mathrm{L}$. & 1.2 & 3.9 & 6.5 \\
\hline Sonchus asper (L.) Hill & 1.2 & 2.2 & - \\
\hline Capsella bursa-pastoris (L.) Med. & 0.4 & 2.2 & 5.9 \\
\hline Thlaspi arvense $\mathrm{L}$. & 0.4 & 1.2 & 2.2 \\
\hline Viola arvensis Murr. & 0.2 & 0.8 & 0.8 \\
\hline Veronica persica Poir. & 0.2 & 0.8 & - \\
\hline Vicia villosa Roth & 0.2 & 0.8 & - \\
\hline Veronica hederifolia $\mathrm{L}$. & 0.2 & - & - \\
\hline Galium aparine $\mathrm{L}$. & - & 0.8 & 0.9 \\
\hline Lamium amplexicaule L. & - & 0.5 & 0.2 \\
\hline Apera spica-venti (L.) P.B. & - & 0.2 & 1.5 \\
\hline Vicia angustifolia L. & - & 0.2 & 0.2 \\
\hline Anagallis arvensis L. & - & 0.2 & 0.4 \\
\hline Number of annual weeds (I) & 39.5 & 58.7 & 70.8 \\
\hline \multicolumn{4}{|l|}{ II. Perennial weeds } \\
\hline Convolvulus arvensis $\mathrm{L}$. & 0.4 & 0.2 & - \\
\hline Cirsium arvense (L.) Scop. & 0.2 & 0.2 & 0.4 \\
\hline Elymus repens (L.) P.B. & - & 1.2 & - \\
\hline Number of perennial weeds (II) & 0.6 & 1.6 & 0.4 \\
\hline Number of species & 18 & 23 & 17 \\
\hline
\end{tabular}

* CT- conventional tillage, $\mathrm{RT}$ - reduced tillage, $\mathrm{HT}$ - herbicide tillage

\section{DISCUSSION}

Pea is characterized by a long period of sprouting and a low initial rate of growth and hence it is easily colonized by weeds. For this reason, it requires careful agronomic management, including an appropriate tillage system [10]. As reported by $\mathrm{Lahm}$ ar [7] and Woźniak [3], disparity may be observed in opinions on the effect of ploughless tillage systems on yielding and weed infestation of crops. Generally, however, the no-till system is believed to increase weed infestation of cultivated crops $[3,8,9,18]$. Also our study demonstrated a significant increase in weed numbers and biomass in the reduced (RT) and herbicide (HT) system compared to the conventional system (CT). This increase may be explained by the 
accumulation of freshly fallen seeds on the soil surface from where they germinate and thus increase weed infestation of the crop $[11,14]$. In the opinion of some authors $[10,18]$, long-term reduced tillage contributes to increased weed infestation. In turn, the studies by Małecka et al. [15] and Faltyn and Kordas [16] demonstrate increased weed colonization of crops under conditions of the ploughing system, compared to reduced tillage and direct sowing. The extent of weed infestation was also observed to depend on the time of assessment. A higher weed density per $\mathrm{m}^{2}$ occurred at the third leaf stage $(13 / 14 \mathrm{BBCH})$ than at the pod development stage $(73 / 74 \mathrm{BBCH})$. It may be explained by multiple seedlings of plants in this period, especially of Chenopodium album L., Stellaria media (L.) Vill. and Capsella bursa-pastoris (L.) Med. At the later time of assessment, the weed community was already predominated by fruiting weeds and seedlings grown from fallen seeds. It was reflected in a higher weight of weeds which in this period was higher than at the third leaf stage. A higher weed density at the third leaf stage $(13 / 14 \mathrm{BBCH})$ was determined in the plots with reduced (RT) and herbicide (HT) tillage than in the plots with the conventional tillage system (CT). According to $\mathrm{C}$ a rdin a et al. [12] and other authors $[13,14]$, the no-till system increases the bank of diaspores in the topsoil which germinate and thereby increase crop colonization by weeds. In our experiment, the increased weed infestation of the pea crop in the reduced (RT) and herbicide (HT) system also resulted from poorer pea sprouting than in the conventional system (CT) as well as from a significantly lower plant density. The tillage system was also observed to affect the species composition of weeds. This trait was also influenced by the pea development stage. At the third leaf stage $(13 / 14 \mathrm{BBCH})$, the crop was colonized by 26 weed species, including 25 annual ones, whereas at the pod development stage $(73 / 74 \mathrm{BBCH})$ the analysis revealed 24 weed species, including 3 perennial ones.

\section{CONCLUSIONS}

The highest weed density per $\mathrm{m}^{2}$ occurred in the plots with the herbicide and reduced tillage systems, whereas significantly lower weed density was found in the conventional plots. In addition, more weeds occurred at the third leaf stage (13/14 in BBCH scale) of pea than at the pod development stage $(73 / 74 \mathrm{BBCH})$.

The highest biomass was produced by weeds in the herbicide system, lower in the reduced and the lowest in the conventional system. Also, a higher air-dry weight of weeds was recorded at the pod development stage $(73 / 74 \mathrm{BBCH})$ than at the third leaf stage $(13 / 14$ $\mathrm{BBCH})$.

The tillage system affected the species composition of weeds. This trait was also influenced by the time of weed infestation assessment. At the third leaf stage $(13 / 14 \mathrm{BBCH})$, the plots were colonized by 26 weed species (including 24 annual ones), whereas at the pod development stage $(73 / 74 \mathrm{BBCH})$ by 24 species of weeds (including 3 perennial ones).

\section{Acknowledgements}

The research supported by Poland's Ministry of Science and Higher Education as part of the statutory activities of the Department of Herbology and Plant Cultivation Techniques, University of Life Sciences in Lublin.

\section{Authors' contributions}

Concept of study: AW; field research and data collection: AW; data interpretation: AW, MS; writing of the manuscript, table: AW.

\section{REFERENCES}

1. Wesołowski A, Woźniak A. Present and potential weed infestation of spring cereals in different cropping system. Acta Agrobot. 2001; 54(1): 175-190. http://dx.doi. org/10.5586/aa.2001.015

2. Gruber S, Claupein W. Effect of tillage intensity on weed infestation in organic farming. Soil Tillage Res. 2009; 105(1): 104-111. http://dx.doi.org/10.1016/j. still.2009.06.001

3. Woźniak A. Weed infestation of pea (Pisum sativum L.) crop under the conditions of plough and ploughless tillage. Acta Sci Pol Hortorum Cultus. 2012; 11(2): 253-262.

4. Knežević M, Baličević R, Ranogajec L. Influence of soil tillage and low herbicide doses on weed dry weight and cereal crop yields. Herbologia. 2009; 10(1): 79-88.

5. Lundkvist A. Effects of pre- and post-emergence weed harrowing on annual weeds in peas and spring cereals. Weed Res. 2009; 49(4): 409-416. http://dx.doi.org/10.1111/ j.1365-3180.2009.00718.x

6. Brandsæter LO, Bakken AK, Mangerud K, Riley H, Eltun R, Fykse H. Effects of tractor weight, wheel placement and depth of ploughing on the infestation of perennial weeds in organically farmed cereals. Eur J Agron. 2011; 34(4): 239-246. http://dx.doi. org/10.1016/j.eja.2011.02.001

7. Lah mar R. Adoption of conservation agriculture in Europe. Land Use Policy. 2010; 27(1): 4-10. http://dx.doi. org/10.1016/j.landusepol.2008.02.001

8. Davis AS, Renner KA, Gross KL. Weed seedbank and community shifts in a long-term cropping systems experiment. Weed Sci. 2005; 53(3): 296-306. http://dx.doi. org/10.1614/WS-04-182

9. Peigné J, Ball BC, Roger-Estrade J, David C. Is conservation tillage suitable for organic farming? A review. Soil Use Manag. 2007; 23(2): 129-144. http://dx.doi. org/10.1111/j.1475-2743.2006.00082.x 
10. Tuesca D, Puricelli E, Papa JC. A long-term study of weed flora shifts in different tillage systems. Weed Res. 2001; 41(4): 369-382. http://dx.doi.org/10.1046/ j.1365-3180.2001.00245.x

11. Tørresen KS, Skuterud R. Plant protection in spring cereal production with reduced tillage. IV. Changes in the weed flora and weed seedbank. Crop Prot. 2002; 21(3): 179-193. http://dx.doi.org/10.1016/S0261-2194(01)00081-3

12. Cardina J, Herms CP, Doohan DJ. Crop rotation and tillage system effects on weed seedbanks. Weed Sci. 2002; 50(4): 448-460. http://dx.doi.org/10.1614/00431745(2002)050[0448:CRATSE]2.0.CO;2

13. Chauhan BS, Gill GS, Preston C. Tillage system effects on weed ecology, herbicide activity and persistence: a review. Aust J Exp Agric. 2006; 46(12): 1557. http://dx.doi.org/10.1071/EA05291

14. Mohler C, Frisch J, Mcculloch C. Vertical movement of weed seed surrogates by tillage implements and natural processes. Soil Tillage Res. 2006; 86(1): 110122. http://dx.doi.org/10.1016/j.still.2005.02.030

15. Małecka I, Blecharczyk A, Dobrzeniecki T. Zachwaszczenie zbóż ozimych w zależności od systemu uprawy roli. / Response of weed community in winter cereals to tillage system. Prog Plant Prot Post Ochr Roślin. 46(2): 253-255. (in Polish)

16. Faltyn U, Kordas L. Wpływ uprawy roli i czynników regenerujących stanowisko na zachwaszczenie pszenicy jarej. / Effect of tillage and field regeneration factors on weed infestation of spring wheats. Fragm Agron. 2009; 26(1): 19-24. (in Polish)

17. Kraska P, Pałys E. Weed infestation in canopy of spring barley in condition of different tillage systems and fertilization and plant protection levels. Acta Agrobot. 2006; 59(2): 323-333. http://dx.doi.org/10.5586/aa.2006.086

18. Woźniak A. Weed infestation of a spring wheat (Triticum aestivum L.) crop under the conditions of plough and ploughless tillage. Acta Agrobot. 2011; 64(3): 133-140. http://dx.doi.org/10.5586/aa.2011.040

19. IUSS Working Group WRB. World reference base for soil resources 2006. Rome: FAO; 2006.

20. Ad a mczewski K, Matysiak K. Kluczdookreślania faz rozwojowych roślin jednoliściennych i dwuliściennych w skali BBCH. Poznań: Institute of Plant Protection; 2002. (in Polish)

\section{Wpływ wieloletnich uproszczeń w uprawie roli na zachwaszczenie grochu siewnego (Pisum sativum L.)}

\section{Streszczenie}

Oceniono zachwaszczenie grochu siewnego (Pisum sativum L.) wysiewanego w warunkach konwencjonalnej (CT), uproszczonej (RT) i herbicydowej (HT) uprawy roli. Wykazano, że największe zagęszczenie chwastów na $\mathrm{m}^{2}$ wystąpiło na obiektach uprawy herbicydowej i uproszczonej, natomiast istotnie mniejsze $\mathrm{w}$ uprawie konwencjonalnej. Również większą biomasę wytworzyły chwasty w uprawie herbicydowej, mniejszą w uprawie uproszczonej, zaś najmniejszą w konwencjonalnej. Uprawa roli wpływała również na skład gatunkowy chwastów. Cecha ta zależała także od terminu oceny zachwaszczenia. W fazie trzeciego liścia grochu najliczniejszymi były: Chenopodium album L., Stellaria media (L.) Vill., Capsella bursa-pastoris (L.) Med., Matricaria inodora L., Thlaspi arvense L. i Fallopia convolvulus (L.) A. Löve. W fazie rozwoju strąków ilościowo dominowaty: Avena fatua L., Amaranthus retroflexus L., Papaver rhoeas L., Echinochloa crus-galli (L.) P.B., Matricaria inodora L. i Galeopsis tetrahit L.

Handling Editor: Elżbieta Weryszko-Chmielewska

This is an Open Access digital version of the article distributed under the terms of the Creative Commons Attribution 3.0 License (creativecommons.org/licenses/by/3.0/), which permits redistribution, commercial and non-commercial, provided that the article is properly cited.

(C) The Author(s) 2014 Published by Polish Botanical Society 